\title{
KKTC Millî Arşiv Belgeleri Işığında Kıbrıs Adası Türk Azınlığı Kurumunun (KATAK) Kıbrıs Türk Toplumu Yararına Yürüttüğü Faaliyetler (1943-1946)
}

\author{
Emrah Balıkçıoğlu* \\ (ORCID ID: 0000-0001-8186-6946) \\ Makale Gönderim Tarihi \\ 01.12.2018 \\ Makale Kabul Tarihi \\ 06.03.2019
}

\section{Özet}

Bu çalışmada Kıbrıs Adası Türk Azınlığı Kurumu'nun (KATAK) 1943-1946 yılları arasında, Kıbrıs Türk Toplumu için eğitim, ekonomi ve kültür alanlarında yürüttüğü faaliyetler ele alınmıştır. Çalışmanın amacı, KATAK'ın Kıbrıslı Türklerin aydın, çağdaş, kalkınmış ve millî bilince sahip bir toplum hâline getirilmesi sürecindeki rolünü göstermektir.

İngiliz idaresi hoşgörüsü sonucu her alanda Türklerden daha gelişmiş hâle gelen Rumlar; enosis (Yunanistan'a ilhak) taleplerini daha yüksek sesle dile getirme olanağı bulmuşlardır. Kıbrıslı Türkler ise Yunanistan'a bağlanmayı, kendi gelecekleri ve güvenlikleri açısından tehdit olarak görmüşlerdir. Bir yandan da toplumsal haklarını geri alma kaygısına düşmüşlerdir. Bu sebeple gerek Rumların enosis taleplerine karşı mücadele etmek, gerekse hakları için İngilizler nezdinde çeşitli girişimlerde bulunmak amacıyla kendi örgütlerini kurmuşlardır. 1943 yılında ortaya çıkan KATAK da bu örgütlenme sürecinin bir parçası olmuştur. KATAK; Kıbrıs Türk Toplumunun ekonomik ve kültürel gelişimine önemli katkılarda bulunmuştur.

Anahtar Kelimeler: Kıbrıs; Türkler; Eğitim; Zanaatkâr; Cumhuriyet.

Activities Carried Out by the Association of Turkish Minority of Cyprus (ATMCI) for the Benefit of the Turkish Cypriot Community in the Light of Documents of the National Archive of the TRNC (1943-1946)

\section{Abstract}

In this study, the educational, economic and cultural activities performed by the Association of Turkish Minority of Cyprus Island (ATMCI) for the Turkish

\footnotetext{
•Dr., emelgil@gmail.com.
}

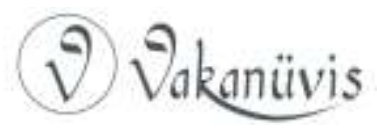


Cypriot community in the years of 1943-1946 were handled. Its aim is to demonstrate the role played by the ATMCI in the process of rendering Turkish Cypriots an intellectual, developed and conscious society.

Greek Cypriots, who had become more prosperous than Turks thanks to the British tolerance, found the opportunity to raise their enosis (union with Greece) demands. On the other hand, Turkish Cypriots regarded union with Greece as a threat to their future and fate. They began to oppose the enosis, while they made efforts for gaining their social rights. Thus, they started to establish their own organizations. One purpose of these organizations was to stand up to the idea of union with Greece, while another one was to appeal to the British rule for the Turkish Cypriots' communal rights. The ATMCI, which was emerged in 1943, was a part of this organization process. The Association played a significant role in the economic and cultural development of the Turkish Cypriot community.

Keywords: Cyprus; Turks; education; craftsmen; republic.

\section{Giriş}

1878 yılında Kıbrıs'ta kurulan İngiliz idaresi ${ }^{1}$, adadaki Türk Toplumu için önemli bir kurum olan Evkaf yönetimini de denetimine alarak², Türkleri yönetim, ekonomi ve eğitim bakımından Rumlardan geri bırakan uygulamalarda bulundu. ${ }^{3}$ Kıbrıs Rum Ortodoks Kilisesi ise İngiliz yönetiminin yarattığı hoşgörü ortamında, Türk düşmanlığını içeren enosis (Yunanistan'a ilhak) faaliyetlerini yürütmeye başladı. ${ }^{4}$

\footnotetext{
${ }^{1}$ Rifat Uçarol, 1878 Cyprus Dispute\&The Ottoman-British Agreement, Rüstem Kitabevi, Lefkoşa, 2000, s.67-73.

${ }^{2}$ Ahmet C. Gazioğlu, Ingiliz Yönetiminde Kıbrıs II (1878-1952), Enosis Çemberinde Türkler, Bugünlere Gelmek Kolay Olmadı (1), íkinci Baskı, CYREP Yayınları, Lefkoşa, 2000, s.394;. Halil Fikret Alasya, Kıbrıs Tarihi ve Kıbrıs'da Türk Eserleri, İkinci Baskı, TKAE, 1977, Ankara, s.124127.

3 K.T.Y.1943.121.01; K.T.Y.04.1944.123.03; K.T.Y. 04.1943.176.01; K.T.Y. 04.1943.176.02; K.T.Y. 04.1943.199.01. Ayrica bkz. Nancy Crawshaw, The Cyprus Revolt, An account of the struggle for union with Greece, George Allen\&Unwin, London, 1978, s.42-43; George Hill, A History of Cyprus, The Ottoman Province. The British Colony, 1571-1948, Cambridge University Press, Cambridge, 2010, s.418.

4 Fikret Kürşad, Mustafa Haşim Altan, Sabahattin Egeli, Belgelerle Kıbrıs'ta Yunan Emperyalizmi, Kutsun Yayınevi, İstanbul, 1978, s.93-97.
}

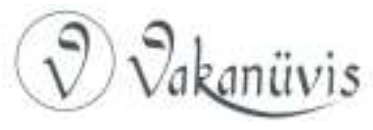


Bu gelişmeler, Kıbrıslı Türkleri örgütlenmeye yöneltti. Bazı Türk aydınları; Kıraathane-yi Osmani'yi (Osmanlı Kıraathanesi) kurdu. Türklerin bu cemiyeti kurmalarının bir nedeni, İngiliz idaresinin Türk toplumunu ihmal ettiğini düşünmeleriydi. Bir diğer nedeni ise Rumların Yunanistan'la birleşme çabalarından endişe duymalarıydı. ${ }^{5}$ Cemiyet, fikirlerini duyurmak ve yaymak için 25 Şubat 1891'de Zaman gazetesini çıkarmaya başladı. ${ }^{6}$ Kıbrısı ıürklerin örgütlenme çabası, sonraki yıllarda da devam etti. 1918'de Kıbrıs Müftüsü Ziyai Efendi ile gazeteci-öğretmen Mehmet Remzi Okan; adanın dört bir yanından gelen delegelerle, Meclis-i Millî adında bir kongre topladı. Bu kongrede Ziyai Efendi'nin, I. Dünya Savaşı'nın sonunda toplanan Paris Barış Konferansı'na katılmasına karar verildi. Müftü, Rumların enosis emellerini protesto edecek ve Kıbrıs'ın hâkimiyetinin yeniden Osmanlı Devleti'ne verilmesini isteyecekti. Ancak İngiliz idaresi; Ziyai Efendi'nin Paris'e gitmesine izin vermedi. Bununla da kalmayarak Meclis-i Millî́nin toplanmasına öncülük eden aydınları etkisizleştirme yoluna gitti. ${ }^{7}$

$\mathrm{Bu}$ baskılara rağmen Türkler, siyasi olmasa da toplumsal alanda birtakım faaliyetlerde bulunmayı sürdürdüler. Ayrıca kendi gazeteleri aracılığıyla görüşlerini kamuoyuna yansıtmaya gayret ettiler. ${ }^{8} 1924$ yılında Müftü Ziyai Efendi; Kıbrıs Türk Cemaat-i Islamiyesi'ni kurdu. Bu cemiyet, öncelikle Kıbrıs Türk Toplumu'nun eğitimde ve hukukta çağdaşlaşmasını sağlama amacını güdüyordu. ${ }^{9}$ Aynı dönemde Halkçılar olarak bilinen aydınlar, yaptıkları çalışmalarla öne çıktılar. Bu aydınlara işadamı Necati Özkan önderlik ediyordu. ${ }^{10}$ Halkçılar, Evkaf yönetiminin sıcak bakmadığı Atatürk inkılâplarını ${ }^{11}$ Kıbrıs Türk Toplumunun benimsemesi için uğraş verdiler. ${ }^{12} 1931$ yılında da Millî Kongre'yi

\footnotetext{
${ }^{5}$ Salâhi R. Sonyel, "Ingiliz Yönetiminde Kıbrıs Türklerinin Varlık Savaşımı”, Belleten, LIX/224 (1995), s.147.

${ }^{6}$ Cemalettin Ünlü,Kıbrıs'ta Basın Olayı,Basın-Yayın Genel Müdürlüğü,Ankara,1981,s.18-20.

7 Sabahattin İsmail ve Ergin Birinci, Kıbrıs Türkünün Varoluş Savaşımında iki Ulusal Kongre, Meclis-i Milli (1918), Milli Kongre (1931), CYREP Yayınları, Lefkoşa, 1987, s.26-37.

8 İsmail ve Birinci, a.g.e., s.45-96.

${ }^{9}$ Gazioğlu, a.g.e., s.191.

${ }^{10}$ Ahmet An, Dinsel Toplumdan Ulusal Topluma Geçiş Süreci ve Kıbrıs Türk Liderliğinin Oluşması (1900-1942), Galeri Kültür Yayınları, Lefkoşa, 1997, s.106-180.

${ }^{11}$ Crawshaw, a.g.e., s.43.

12 Derviş Manizade, Kıbrıs, Dün, Bugün, Yarın, Kıbrıs Türk Kültür Derneği Yayınları, İstanbul, 1975, s.15; Sabahattin İsmail ve Ergin Birinci, Atatürk Döneminde Türkiye-Kıbrıs Ilişskileri
}

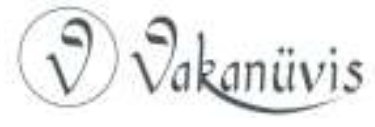


düzenlediler. Kongrede Kıbrıslı Türklerin toplumsal haklarına ilişkin İngiliz Sömürge Yönetimi'ne sunulacak talepler belirlendi. ${ }^{13}$

Ne var ki Türkler, bu talepleri sömürge idaresi nezdinde dile getirme olanağı bulamadı. Zira 1931 sonbaharında Rumlar, Yunanistan'la birleşmek için başarısız bir isyan girişiminde bulundular. ${ }^{14}$ Bunun üzerine İngiliz Sömürge Yönetimi, adanın tamamını kapsayan bir sıkıyönetim ilan etti. ${ }^{15}$ 1941'e kadar devam eden sıkıyönetim, II. Dünya Savaşı'ndan kaynaklanan kritik dönem dikkate alınarak gevşetildi. ${ }^{16}$ Gerek Türkler, gerekse Rumlar, bu ortamdan faydalanarak yeni bir örgütlenme süreci başlattılar. Bu dönemde ilk kurulan Kıbrıs Türk örgütü, Kıbrıs Adası Türk Azınlığı Kurumu (KATAK) oldu.

KATAK'la ilgili eserler incelendiğinde bu konuyu ele alan araştırmacıların, örgütün siyasi ve toplumsal işlevi hakkında farklı görüşler öne sürdügü görülmektedir. Bazı araştırmacılara göre KATAK, Rumların Kıbrıs'ı Yunan idaresine bağlama çabalarına karşı Türklerin desteğini almak isteyen İngilizlerin telkiniyle kurulmuştur. ${ }^{17}$ Bazı araştırmacılar da İngilizlerin etkisini kabul etmekle birlikte, örgütün kuruluşunda farklı amaçlar olduğu görüşündedir. Onlara göre KATAK, hem Rumların Yunanistan'la birleşme emellerine karşı durmak, hem de Kıbrıs Türk Toplumu'nu İngilizlerin ada halkına tanıyacağı özerkliğe hazırlamak için ortaya çıkmıştır. ${ }^{18}$ Bu makalede ise KKTC Millî Arşiv ${ }^{19}$ belgeleri ışığında, örgütün toplumsal ve kültürel faaliyetleri ele alınacaktır. Makalenin amacı, KATAK'ın Kıbrıs Türk Toplumu'nun eğitim, ekonomi ve kültür hayatının gelişim sürecinde önemli bir rolü olduğunu

(1919-1938), Akdeniz Haber Ajansı Yayınları, Lefkoşa, 2000, s. 218-274.

13 İsmail ve Birinci, iki Ulusal Kongre, s.108-123.

14 İzzet Öztoprak, "Kıbrıs'ta 1931 İsyanı ve Yankıları (3 sayfa belge ile birlikte)", Belleten, LXII/233 (1998), s.215-217.

${ }^{15}$ Crawshaw, a.g.e., s. 43; Gazioğlu, a.g.e., s. 253-270.

${ }^{16}$ Crawshaw, a.g.e., s.30-31.

17 Nazım Beratlı, Kıbrıslı Türklerin Tarihi, Ingiliz Dönemi, Cilt 3, Galeri Kültür Yayınları, Lefkoşa, 1999, s.148; Niyazi Kızılyürek, Milliyetçilik Kıskacında Kıbrıs, İletişim Yayınları, İstanbul, 2002, s.224.

18 Gazioğlu, a.g.e., s.335-344; Haşmet M. Gürkan, Bir Zamanlar Kıbrıs'ta (Tarih yazıları) (1860-1945), CYREP Yayınları, Lefkoşa, 1986, s.134; Sibel Akgün, "1942-1943 Arası Dönemde Kıbrıs Türk Kimliğinin IIlk Kurumsallaşma Hareketleri”, Turkish Studies, 7/3 (2012), s.135-136.

${ }^{19}$ Söz konusu arşiv belgeleri dipnotta K.T.Y. kısaltmasıyla gösterilecektir.

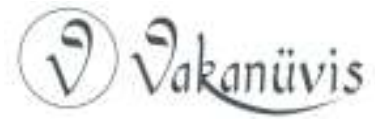


göstermektir. Örgütün bu rolünün daha iyi kavranabilmesi için de öncelikle hangi koşullarda kurulup geliştiğine bakmak faydalı olacaktır.

\section{KATAK'ın Kuruluş ve Örgütlenme Süreci}

II. Dünya Savaşı'nın ilk yıllarında İngiltere'nin Kıbrıs'ın siyasi statüsüne ilişkin planları, adadaki Türklerin örgütlenmeye yönelmesinde başlıca etken olmuştu. Nitekim dönemin İngiliz Sömürgeler Bakanı Oliver Stanley, Atlantik Bildirisi'nin ${ }^{20}$ ruhuna uygun şekilde Kıbrıs halkına özerklik tanınacağını açıklamıştı. ${ }^{21} 31$ Mart 1943 tarihinde ise Sömürgeler Bakanlığı Müsteşarı Edward Cavendish (Devonshire Dükü), Lordlar Kamarası'nda yaptığı konuşmada Kıbrıs'a aşamalı olarak özerklik (self-government) vereceklerini ifade etmişti. ${ }^{22}$

$\mathrm{Bu}$ açıklamaların Kıbrıs kamuoyuna farklı yansımaları oldu. Kıbrıslı Rumlar, özerklik fikrine sıcak bakmadılar. Rum görüşüne göre Yunanistan, Almanya'ya karşı İngiltere'nin safında savaşıyordu. Bu da savaşın sonunda Kıbrıs'ın bir ödül olarak Yunan yönetimine bırakılacağı anlamına geliyordu. ${ }^{23}$ Özellikle Kıbrıs Rum Kilisesi ile milliyetçi görüşe sahip Rumlar, özerkliğe çekinceli yaklaştılar. Onların inancına göre Kıbrıs Rum toplumu, özerkliğin idari ve ekonomik yönlerden Yunan yönetiminden daha faydalı olduğunu düşünebilir; böylece enosis hedefinden uzaklaşabilirdi. Bu inanç nedeniyle olsa gerek, hem kilise hem de milliyetçi Rumları temsil eden kurum ve kuruluşlar, İngiltere Başbakanı Churchill'e ve Sömürgeler Bakanına, Yunanistan'a ilhakın yegâne arzuları olduğunu bildiren telgraflar gönderdiler. ${ }^{24}$

Kıbrıslı Türklerin özerklik konusundaki tavırları ise önde gelen Türk gazetelerinden biri olan Söz gazetesinin yayınlarında görülebiliyordu.

2014 Ağustos 1941 tarihinde ABD Başkanı Franklin D. Roosevelt ile İngiltere Başbakanı Winston Churchill arasında imzalanan ve sekiz maddeden oluşan bu bildirinin 3. maddesi şöyleydi: “iki devlet (ABD ve İngiltere), bütün halkların çatısı altında yaşayacakları kendi hükümet şekillerini seçme hakkına saygı gösterir ve egemenlik haklarından ve özerklikten zorla mahrum edilmiş halklara bunların geri verilmesini arzu eder.", https://www.unmultimedia.org/searchers/yearbook/page.jsp?volume=1946-47\&page=3 $7 \&$ srq=atlantic\&srstart=0\&srvolumeFacet=1946-47\&sroutline=false\&searchType=advanc ed, 24.11.2018.

${ }^{21}$ Gazioğlu a.g.e., s.335.

22 HL Deb, 31 March 1943, vol 126, c1036.

${ }^{23}$ Akgün, a.g.m., s.135.

${ }^{24}$ Gürkan, a.g.e., s.138-139.

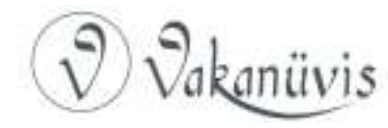


Gazetenin 30 Mart 1943 tarihli başyazısında özetle şu fikirler savunuluyordu: Kıbrıs'a özerklik tanımak, nüfus bakımından azınlıkta olan Türklerin hukukunu Rumlara feda etmek demekti. Ayrıca Türklerin hukuku dikkate alınmadan özerk yönetim kurulacak olursa, Rumlar Türklere duydukları kin ve intikamı feci bir şekilde alabilirdi. Bu durumda Türklere düşen en büyük görev, özerkliğin adadaki azınlıklar için kabul edilebilir olmadığını Londra'ya, hatta dünya kamuoyuna duyurmak olmalıydı. Dahası Türklerin istediği özerklik değil, hâlen mahrum oldukları toplumsal haklarıydı. ${ }^{25}$

Aynı günlerde Kıbrıs halkının tamamını temsil ettiği iddiasında bulunan Rum belediye başkanları ile belediye meclis üyeleri, İngiltere Hükümeti'ne başvurarak adanın Yunanistan'a ilhak edilmesi talebinde bulundular. Buna karşı Lefkoşa belediye meclisinin Türk üyeleri Dr. Fazıl Küçük, Necmi Avkıran, Şükrü Veysi ve Necati Özkan; gerek Başbakan Churchill'e, gerekse Sömürgeler Bakanına, Rumların bu talep ve iddialarını protesto eden bir telgraf çektiler. Bunları Kıbrıs'ın diğer kazalarındaki Türk belediye meclis üyeleri ile Türkleri temsil eden bazı kurum ve kuruluşların benzer içerikteki telgrafları izledi. ${ }^{26}$

Bu dönem, aynı zamanda milliyetçi fikirleri savunan Türk aydınları ile gençlerinin toplumun sorunlarına ve enosis tehlikesine karşı çözüm yollarını tartıştığı bir dönemdi. ${ }^{27} \mathrm{Bu}$ tartışmalarda siyasi örgütlenme yönünde adım atılması fikri de şekillenmeye başladı. Kıbrıs Türk basınında da birlik beraberliğe ve örgütlenmeye olan ihtiyacı vurgulayan yazılar çıkmaktaydı. Nitekim 26 Mart 1943 tarihli Söz gazetesinde yayımlanan bir yazıda, Türk toplumunun tam, geniş ve gerçek bir işbirliğine gereksinimi olduğu savunularak Türklerin en erken zamanda hazırlıklı ve örgütlü olması zorunluluğu vurgulanıyordu. Bu zorunluluğu yaratan etkenler ise şöyle sıralanıyordu: Türk toplumunun varlığını sürdürme ve kendisinden daha ilerde olan Rumların baskısı altında ezilmeme ihtiyacı, çok önemli toplumsal işler ve sorunlar için hep beraber görüşülerek önlemler alınması gerekliliği, özerklik anayasasının tanıyacağı hak ve yetkilerin bilinçli şekilde kullanılması ve daha fazlasının

\footnotetext{
25 Gürkan, a.g.e., s.142-143.

${ }^{26}$ K.T.Y.04.1943.07.01; Gürkan, a.g.e., s.140-141.

${ }^{27}$ Rauf Raif Denktaş, Elli Yılın Hikâyesi, Akdeniz Haber Ajansı Yayınları, İstanbul, 2008, s.2829, 41-42.
}

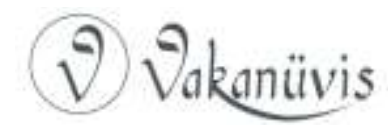


hak edildiğinin kanıtlanması. Yazıda böyle bir işbirliğinin oluşmasına öncülük edecek olanların ise Lefkoşa'nın Türk belediye meclis üyeleri olduğu savunuluyor; bu kişiler görev başına çağrılıyordu. ${ }^{28}$

Bütün Türkleri bir araya getirmek amacına hizmet edecek bir siyasi örgüt kurma yönünde ilk adımı atan ise Necati Özkan oldu. ${ }^{29}$ Özkan; Dr. Fazıl Küçük ile arkadaşlarına Kıbrıslı Türklerin istek ve şikâyetlerini sömürge hükümetine iletmelerine aracılık edecek bir siyasi parti kurma teklifinde bulundu. ${ }^{30}$ Bu sırada Evkaf Murahhası Mehmet Münir de böyle bir örgüt kurulması için toplantı yapılması önerisini getirdi. ${ }^{31}$ Bir yandan da Türk toplumunun önde gelenleriyle görüşüp siyasi bir örgüt kurulması yönünde telkinlerde bulunmaya başladı. Mehmet Münir, bu görüşmelerde, kurulacak örgütün Kıbrıslı Türklerin hem adanın Yunanistan'a ilhakı tehlikesine karşı birlik içinde mücadele etmesini, hem de özerk yönetime hazır hâle gelmesini sağlayacağını savundu. Ayrıca kendisinin gerek örgütün kurulmasına, gerekse sömürge hükümetiyle ilişkilerini yürütmesine yardım edebileceğini bildirdi. Mehmet Münir, kuruluş toplantısının da Evkaf Dairesi'nin salonunda yapılmasını önerdi. Görüşmelerde yer alan Türk toplum ileri gelenleri de Münir Bey'in siyasi örgüt kurma önerisini olumlu karşıladılar. ${ }^{32}$

Bu görüşmeler devam ederken Lefkoşalı Türkler, 9 Nisan 1943'te örgütü kuracak vekil ve delegeleri seçtiler. ${ }^{33} 14$ Nisan'da da Dr. Fazıl Küçük, Necmi Avkıran, Şükrü Veysi ve Necati Özkan; Söz gazetesinin sayfalarından başkentte yaşayan Türkleri örgütün dört gün sonra yapılacak kuruluş toplantısına davet ettiler. ${ }^{34}$ Nihayet 18 Nisan'da Lefkoşa'nın serbest meslek sahiplerini, esnaf ve zanaatkârını oluşturan

\footnotetext{
${ }^{28}$ Gürkan, a.g.e., s.144-145.

29 Ulvi Keser, Çanakkale Esirleri, Ermeni Doğu Lejyonu, Milli Mücadele, Dr. Behiç Bey, EOKA, Türk Mukavemet Teşkilatı, KTKF, Megali Idea, Ermeniler, 20 Temmuz 1974 ve Annan Planında, Dünden Bugüne Kıbrıs (1913-2013), Dü. Cuma Ağca, Berikan Yayınevi, Ankara, 2013, s.120.

${ }^{30}$ Akgün, "a.g.m., s.138; Keser, a.g.e., s.119.

${ }^{31}$ Akgün, a.g.m., s.137; Gazioğlu, a.g.e., s.231, 242, 269.

32 Gürkan, a.g.e., s.145-146.

33 K.T.Y.04.1943.10.01; K.T.Y.04.1943.11.01; K.T.Y.04.1943.12.01; K.T.Y.04.1943.13.01; K.T.Y.04.1943.14.01; K.T.Y.04.1943.15.01.

${ }^{34}$ Gürkan, a.g.e., s.146.
}

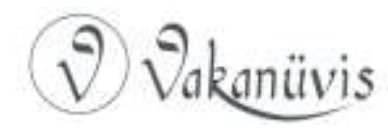


76 kişi $^{35}$, Evkaf Dairesi salonunda bir araya geldi. ${ }^{36}$ Toplantıda avukat Fadıl N. Korkut tarafından hazırlanan ve "KATAK Anayasası" olarak adlandırılan bir tüzük kabul edildi. ${ }^{37}$ Yaklaşık 30 maddeden ${ }^{38}$ oluşan bu tüzüğün 3. maddesinde "örgütün amacının; Kıbrıs'ta yaşayan Türklerin haklarını aramak ve korumak, bilimsel, toplumsal, sınai ve ekonomik düzeylerini yükseltmek ve genel olarak Kıbrıs Türklerinin çıkarlarını sağlamaya çalışmak" olduğu ifade ediliyordu. ${ }^{39}$ Daha sonra örgütün ismi tartışılarak "Kıbrıs Adası Türk Azınlığı Kurumu" adı verilmesine karar verildi. ${ }^{40}$ Toplantının sonunda ise "Faal Heyet" adını taşıyan merkezî çalışma grubu belirlendi. Heyet şu kişilerden oluşuyordu: Dr. M. Rauf (Başkan), Mehmet İzzet (Başkan Yardımcısı), Fadıl Korkut (Genel Sekreter), Dr. Pertev Zühtü (Faal Üye), Necmi Avkıran (Veznedar), Necati Özkan (Faal Üye), Dr. Fazıl Küçük (Faal Üye), Şükrü Veysi (Tahsildar) ve Eczacı Mehmet Münir (Faal Üye). ${ }^{41}$ Mehmet İzzet, Dr. M. Rauf, Fadıl Korkut, Necmi Avkıran ve Şükrü Veysi ise merkez yönetim kurulunu oluşturuyordu.

KATAK'ın yapısına ilişkin iki önemli hususun öne çıktığı görülmekteydi. Öncelikle Kurum'un yönetiminde bulunan isimler, yalnız Kıbrıs Türk Toplumu içinde değil; sömürge hükümeti nezdinde de saygınlığı olan ve hükümetin güvenini kazanmış kişilerdi. Kamuoyuna da yansıdığına göre sömürge hükümetinin muhatap kabul edeceği değerli kişileri Kıbrıslı Türklerin temsilcisi yapmak, KATAK'ın başlıca ilkeleri arasındaydı. Bu ilke, Kurum'un benimsediği, Türklerin hak ve çıkarlarını sömürge idaresini tedirgin etmeden arama ve koruma kuralına da uygundu. ${ }^{42}$ Bir diğer önemli husus da o güne dek siyasi rekabet, çekişme veya anlaşmazlık içinde olan toplum önderlerinin aynı örgütte buluşmalarıydı. Nitekim o günlerde Dr. Küçük, Türkler arasında yıllardan beri süregelen çekiştirme, dedikodu ve particiliğin maziye gömüldüğü ve

\footnotetext{
${ }^{35}$ Bazı araştırmacılara göre 79 kişi; bu konuda bkz. Beratlı, a.g.e., s.148.

${ }^{36}$ Keser, a.g.e., s.118-119.

37 Gürkan, a.g.e., s.146-148.

${ }^{38}$ Beratlı, a.g.e., s.148; Rukiye Maden, Dr. Fazıl Küçük ve Kıbrıs, Tarihçi Kitabevi Yayınları, İstanbul, 2014, s.26-31; K.T.Y.04.1943.78.01; K.T.Y.04.1943.73.01; K.T.Y.04.1943.75.01; K.T.Y.04. 1947. 49.02; K.T.Y.04. 1947. 61.01; K.T.Y.04.1943.71.02; K.T.Y.04.1943.71.06.

${ }^{39}$ K.T.Y.04.1943.71.10.

${ }^{40}$ Gürkan, a.g.e., s.147-148; Keser, a.g.e., s.119-120.

${ }^{41}$ K.T.Y.04.1943.80.01.

${ }^{42}$ Gürkan, a.g.e., s.149.
}

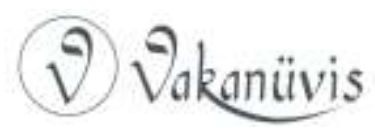


onun yerine bir birlik doğduğu görüşünü savunmaktaydı. ${ }^{43}$ Evkaf Murahhası Mehmet Münir de basına yaptığı açıklamalarda, Kıbrıslı Türkler arasında ikilik olduğu iddialarını yalanlıyor; KATAK'ın üyeleriyle yaptığı görüşmelerde kimsenin Türkler arasına ikilik sokamayacağını söylüyordu. ${ }^{44}$

\section{KATAK'ın Kıbrıs Türk Toplumu Yararına Yürüttüğü Çeşitli Faaliyetler}

KATAK'ın kurulması, Kıbrıs Türk kamuoyunca olumlu karşılandı. Nitekim bu konuda bir yazı kaleme alan Türk toplum önderlerinden avukat Süleyman Hakkı, Kurum'un hem enosis fikrine karşı etkili ve örgütlü bir tepki verilmesini sağlayacağı, hem de Kıbrıslı Türklerin gelişmesine ve kalkınmasına rehberlik edeceği inancını dile getirdi. ${ }^{45}$ KATAK'ın kuruluşunda yer alan Hasan F. Uzman da 28 Nisan 1943 tarihli Söz gazetesinde yayımlanan yazısında, sömürge hükümetinin KATAK'ın oluşturulmasına izin vermesinin, Kıbrıs Türk Toplumunun özgüvenini artırdığını savundu. Uzman'a göre Evkaf Murahhası Münir Bey'in, KATAK'ın Evkaf Dairesi salonunda kurulmasına imkân sağlaması ve Türk toplumunun birliği yönünde açıklamalar yapması, Türklerde büyük bir memnuniyet yaratmıştı. ${ }^{46}$

Kıbrıs Türk toplumu da KATAK'a yoğun ilgi gösterdi. Kurum, kurulduktan sonraki iki hafta içinde başta Lârnaka ve Baf olmak üzere bütün kazalarda şubeler açtı. ${ }^{47}$ KATAK, bir yandan köylerde örgütlenirken ${ }^{48}$, diğer yandan köy şubelerinin belirlediği temsilcilerin kazalarda bir araya gelmesiyle federasyonlar meydana getirdi. ${ }^{49}$ Daha sonra bu federasyonların birleşmesiyle KATAK, 5 Şubat 1944'te bir

\footnotetext{
${ }^{43}$ Maden, a.g.e., s. 26-27.

${ }^{44}$ Gürkan, a.g.e., s. 153.

45 K.T.Y.04.1943.77.01; K.T.Y.04.1943.77.02; K.T.Y.04.1943.77.03; K.T.Y.04.1943.77.04;

K.T.Y.04.1943.77.05.

46 Gürkan, a.g.e., s. 152-153.

47 Gürkan, a.g.e., s.150-152; K.T.Y.04.1943.83.01.

48 K.T.Y.04.1943.98.01; K.T.Y. 04.1943.170.01; K.T.Y.04.1943.183.01; K.T.Y.04.1944.68.01;

K.T.Y.04.1944.69.01.

${ }^{49}$ K.T.Y.04.1943.190.01; K.T.Y.04.1943.190.02; K.T.Y.04.1943.190.03; K.T.Y.04.1943.190. 04.
} 
konfederasyon hâline geldi. ${ }^{50} \mathrm{Bu}$ arada çok sayıda Kıbrıslı Türk de KATAK'a üye olmaya başladı. ${ }^{51}$ Kurum'a doğrudan dilekçeyle üyelik başvurusu yapanlar olduğu gibi ${ }^{52}$, örgütün önderlerinin veya önde gelenlerinin teklifiyle üye yapılan çeşitli meslek sahipleri de mevcuttu. ${ }^{53}$ Üyeliğe önerilenler arasında esnaf, hayvancılar, fabrikatörler, işçi, memur vs. bulunuyordu. ${ }^{54} \mathrm{Bu}$ da her sınıftan Türk'ün aynı örgütün çatısı altında birleştiği anlamına gelmekteydi. Kıbrıslı Türkler, KATAK'a üye olmanın yanı sıra maddi destek de verdi. Kimileri üyelik aidatı yatırırken ${ }^{55}$, kimileri de ianede bulunmakta veya bağış yapmaktaydı. ${ }^{56}$

Böylece kitlesel ve parasal destek elde eden KATAK, kısa sürede Kıbrıs Türk toplumu yararına girişim ve faaliyetlere yöneldi. ${ }^{57}$ il|gi ve çözüm bekleyen en önemli alanlardan biri kuşkusuz eğitimdi. Kurum'un bu alanda tespit edilebilen ilk girişimi, 1943 yılının Eylül ayı sonlarında Baf'ın Agios Merkourios köyüne bir ilkokul açmak ve okula müdür atamak oldu. KATAK, bunun için İngiliz Sömürge Yönetimi nezdinde girişimlerde bulundu. ${ }^{58}$ Genel Sekreter Fadıl Korkut, 30 Eylül 1943'te İngiliz Eğitim Müdürü'ne gönderdiği mektupta, okulu açmaktaki başlıca amaçlarının, Türk çocuklarına İslâm dinini ve Türkçeyi öğretmek olduğunu ifade etmekteydi. ${ }^{59}$ Korkut, mektubuna eklediği okul için resmi izin talep eden metinde de Agios Merkourios köyündeki Türklerin cami ve okuldan yoksun olduklarını, bu sebeple dinî ibadetlerini ve dillerini bilmediklerini, gençlerin dinlerini değiştirdiğini ve KATAK'ın köye bu yüzden okul açmak

\footnotetext{
50 Maden, a.g.e., s.27-28; K.T.Y.04.1943.188.01; K.T.Y. 04. 1943. 198.01; K.T.Y. 04. 1943. 200. 01.

${ }^{51}$ K.T.Y.04.1943.109.01.

52 K.T.Y.04.1943.81.02.

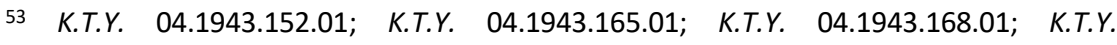
04.1943.171.01.

54 K.T.Y.04.1943.103.01; K.T.Y.04.1943.107.01; K.T.Y.04.1943.112.01; K.T.Y.04.1943. 116.01.

${ }^{55}$ K.T.Y.04.1943.99.06, K.T.Y.04.1943.99.07.

${ }^{56}$ K.T.Y.04.1943.84.01; K.T.Y.04.1943.111.01; K.T.Y.04.1944.91.01; K.T.Y.04.1944.92.02.

${ }^{57}$ K.T.Y.04.1944.104.01; K.T.Y.04.1944.103.04; K.T.Y.04.1944.103.05.

${ }^{58}$ K.T.Y. 04.1943.128.01.

${ }^{59}$ K.T.Y. 04.1943.129.01.
}

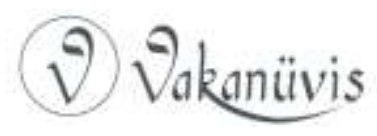


istediğini belirtti. ${ }^{60}$ Bütün bu çabalara rağmen sömürge hükümeti, okul için gereken izni vermedi. ${ }^{61}$

KATAK, Agios Merkurios köyüne ilkokul açma tasarısını hayata geçiremediyse de eğitim alanında yürüttüğü diğer çalışmalarla bazı olumlu sonuçlar almayı başardı. KATAK mensuplarından oluşan bir heyet, 1943 Ekim'inde sömürge idaresine bağlı Lise Komisyonu'yla görüşerek, Türk öğrencilere koğuş, hazırlık sınıfına da dershane verilmesini, 12 ilâ 14 yaş arasındaki hazırlık sınıfı öğrencilerinin ise ilkokullara alınmasını sağladı. ${ }^{62} 10$ Kasım'da da Fadıl Korkut, okuma yazma bilmeyen Türkler için gece okulu açma talebiyle Eğitim Dairesi'ne başvurdu. ${ }^{63} \mathrm{Bu}$ kez resmi izin almayı başaran KATAK, Lefkoşa Halk Kulübü'nün yardımıyla okul için bir de oda tahsis etti. ${ }^{64}$ Böylece gece okulu, Lefkoşa'da öğretime başladı.

KATAK'ın eğitime yönelik faaliyetleri gece okuluyla sınırlı kalmadı. 1944'ün Mayıs ayı sonlarında, KATAK içinde Lefkoşa dışındaki kaza merkezlerinde, hatta büyük köylerde Türk çocuklarına ortaokul açılması konusu gündeme geldi. ${ }^{65}$ Konuyla ilgili olarak KATAK Baf Şubesi Sekreteri Mehmet Dânâ, 22 Haziran 1944 tarihinde Fadıl Korkut'a gönderdiği mektupta, İngiliz Sömürge Yönetimi'nin dört kaza merkezinde ortaokul açamaması durumunda, KATAK'ın ortaokul açılabilmesi için en erken zamanda sömürge hükümeti nezdinde girişimde bulunması gerektiğini belirtti. ${ }^{66}$ Temmuz ayının sonuna doğru ise KATAK, İngiliz Eğitim Müdürü'yle görüşerek, kaza merkezlerinde ortaokul açılması talebinde bulundu. Müdürden olumlu cevap alan Kurum, birkaç hafta sonra da konuyu Evkaf Murahhası ve Türk Ortaokulları Komisyonu Başkanı Mehmet Münir'le görüştü. Mehmet Münir, görüşmede Baf ve Limasol kazalarında birer ortaokul açılmasına yönelik hükümetin kesin karara vardığını bildirdi. KATAK'ın ikinci kez görüştüğü Münir, okul konusunda Eğitim Müdürü'yle fikir birliğine vardıklarını belirterek, yakında toplanacak Türk Ortaokulları Komisyonu'nun kararının beklenmesini

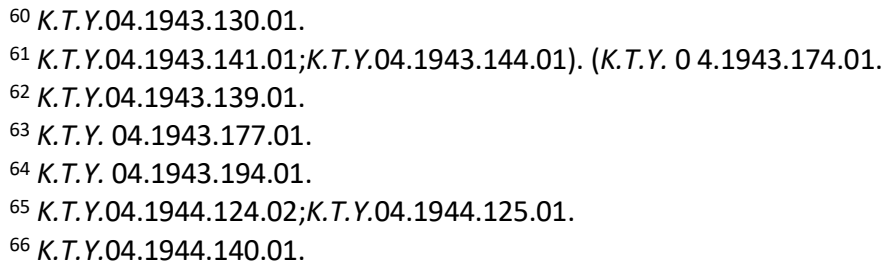


tavsiye etti. Kendisinin de ortaokul açılmasından yana olduğunu sözlerine ekledi. Alınan bilgiye göre, komisyonun diğer Türk üyesi Şevket Bey de okul açılmasına sıcak bakıyordu. Böylece Lise Komisyonu'nda Türkler lehine bir durum olduğunu tespit eden KATAK, komisyondan çıkacak kararı beklemenin uygun olduğu sonucuna vardı. ${ }^{67}$

Bu arada adanın kuzeyinde bir bölge olan Lefke'de ortaokul açılması için KATAK'a başvurular gelmeye başladı. Lefkeli S.M. Tahsin isimli bir Türk, 15 Eylül 1944'te Kurum'un Başkanlığına bu konuda bir mektup yazdı. Mektubunda ilkokulu bitirip ortaokula girme hakkına sahip olan kunduracı yamağı oğlunun, öğrenimine devam edebilmesi için bölgede bir ortaokul açılmasını istiyordu. ${ }^{68}$ Lefke Belediye Başkanı da 19 Mart 1945 tarihinde İngiliz Maarif Müdürü J.R. Cullen'e, bölgede ortaokul açılmasını talep eden ve bir binayı da bu amaç için tahsis etmeye hazır olduğunu bildiren bir mektup gönderdi. Cullen ise 5 Nisan'da mektuba verdiği cevapta, Lefke'de bir ortaokul açılmasına olumlu baktığını, bölgenin okul için çok elverişli olduğunu ama ertesi yılın dersleri için öğretmen kadrosu belirlenmeden bu konuda bir karar alınamayacağını belirtti. Bununla birlikte önerilen binayı incelemek ve yapılması gereken onarım ve eklerle ilgili rapor vermek üzere Okul Binaları Müfettişi'ni bölgeye göndereceğini bildirdi. ${ }^{69} \mathrm{Bu}$ konuyla ilgili belgeler incelendiğinde Lefke'de bir okul açılıp açılmadığı anlaşılamamaktadır. Yalnız 1945 Kasım'ında Türk Ortaokulları Komisyonu'nun Mağusa, Limasol ve Baf'ta birer ortaokul açılmasına ilişkin bir karara vardığı görülmektedir. ${ }^{70}$ Kesin bir sonuca varmak mümkün olmamakla birlikte, böyle bir karara varılmasında KATAK'ın çabalarının da etkili olduğu kanaati oluşmaktadır.

KATAK'ın ilgilendiği eğitimle bağlantılı bir diğer sorun da parasızlıktı. Bu sorundan dolayı aileler çocuklarını okutamıyor, öğrenciler okulun istediği yemek parası ile duhuliyeyi (okula giriş ücreti) vermekte zorlanıyordu. KATAK, bu soruna da eğilip çözmek için gayret gösterdi.

\footnotetext{
${ }^{67}$ K.T.Y.04.1944.148.02; K.T.Y.04.1944.152.01; K.T.Y.04.1944.162.02.

68 K.T.Y.04.1944.185.01.

${ }^{69}$ K.T.Y.04.1945.167.01.

70 K.T.Y.04.1945.233.12; K.T.Y.04.1945.233.13; K.T.Y.04.1945.233.14; K.T.Y.04.1945.233. 15.
}

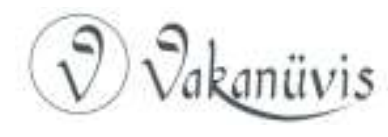


Örgütün halktan bağış toplayarak ${ }^{71}$ öğrencilere yemek parası yardımında bulunması, bu türden çalışmalara bir örnekti. ${ }^{72}$

$\mathrm{Bu}$ genel yardımların yanında kazalarda kurulan örgüt şubeleri aracılığıyla da öğrencilere destek olunmaktaydı. Bunlardan biri olan Limasol Şubesi, 28 Eylül 1945 tarihinde merkezi şubeye gönderdiği mektupta, hâlihazırda ödenmekte olan Limasollu Yaşar Mehmet'in yemek parası ile Limasol'a bağlı Polemidya'dan (Binatlı) Ethem Mehmet'in koğuş ve okul ücretini 1945-1946 ders yılında da ödemeye karar verdiklerini bildirmekteydi. ${ }^{73} 25$ Kasım'da da KATAK Konfederasyonu, bir toplantı yaparak zor durumda olan Türk öğrencilere yardım edebilmeleri için 200 sterlinlik bir meblağı Kurum'un Lefkoşa, Lârnaka, Limasol, Baf ve Mağusa şubeleri arasında paylaştırdı. ${ }^{74}$ Yine Genel Merkez; Lârnaka ve Limasol şubelerinden gelen talepler doğrultusunda, İslâm Lisesi'nde okuyan bazı öğrencilerin karşılayamadığı yemek parası için okula bir miktar ödeme yaptı. ${ }^{75}$

Duhuliye de KATAK tarafından karşılanan okul masrafları arasındaydı. Kurum, Kıbrıslı Türklerden gelen dilekçeleri değerlendirerek hangi öğrencilerin duhuliyesini ödeyeceğine karar vermekteydi. ${ }^{76}$ Limasol'un Bladanisya (Çamlıca) köyünden Fatma M. Nurettin, 18 Mart 1944 tarihli dilekçesinde öksüz kalan oğlu Ali Osman Mehmet'in duhuliyesini ödeyecek güçte olmadığını ifade ederek yardım isteyince ${ }^{77}$ bu isteği KATAK tarafından yerine getirildi. ${ }^{78}$ Yine Kurum, sakat babasının çalışamaması yüzünden duhuliyesini veremeyen Lârnaka'nın Köfünye (Geçitkale) köyü sakini Selim Emirali adlı öğrencinin giriş ücretinin yarısını ödedi. ${ }^{79}$ Aynı şekilde Baf'a bağlı Ktima'da (Yukarı Baf) oturan

\footnotetext{
${ }^{71}$ K.T.Y.04.1943.1.1.

72 K.T.Y.04.1944.05.01; K.T.Y.04.1944.98.02; K.T.Y.04.1944.98.03; K.T.Y.04.1944.100.01.

${ }^{73}$ K.T.Y.04.1945.212.01; K.T.Y.04.1945.217.02.

${ }^{74}$ K.T.Y.04.1945.231.03.

${ }^{75}$ K.T.Y.04.1945.235.01; K.T.Y.04.1945.236.01; K.T.Y.04.1945.237.01.

${ }^{76}$ K.T.Y.04.1944.04.01; K.T.Y.04.1944.50.01;K.T.Y.04.1944.50.04; K.T.Y.04.1944.50.05.

77 K.T.Y.04.1944.52.02

${ }^{78}$ K.T.Y.04.1944.89.03;K.T.Y.04.1944.115.02; K.T.Y.04.1944.118.01; K.T.Y.04.1944.120.01.

${ }^{79}$ K.T.Y.04.1944.173.01; K.T.Y.04.1944.173.01; K.T.Y.04.1944.186.01;K.T.Y.04.1944.186.02; K.T.Y.04.1944.186.03.
}

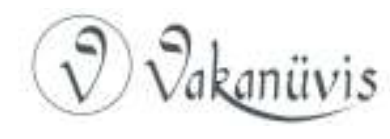


Ahmet Ibrahim Kahveci'nin dilekçesi üzerine oğlu Tahsin Ahmet'in duhuliye parası, KATAK tarafından karşılandı. ${ }^{80}$

Kurum, ortaokul öğrencilerine parasal destek sağlamanın yanı sıra yüksek öğrenim görmek üzere Türkiye'ye öğrenci göndermek veya yurtdışında okuyan öğrencilere maddi yardım yapmak için de uğraş verdi. ${ }^{81}$ Özellikle Türkiye'ye öğrenci gönderilmesine büyük önem verilmekteydi. Türkiye de Kıbrıs'taki konsolosluğu aracılı̆̆ıyla bu çalışmalara destek oluyordu. Konsolos'un Türkiye Hükümeti'nin Kıbrıslı Türklerin eğitimi için kolaylık göstereceği sözünü vermiş olması da bunun en somut ifadesi olsa gerekti. Bunu dikkate alan KATAK, 1944 Aralık'ında toplanarak Kıbrıs Türk toplumunun ihtiyaç duyduğu meslekleri tespit etti. Kazalardaki şubelerden de bu konuda görüş istedi. Gelen çeşitli öneriler ve yapılan tartışmalar sonucunda şu mesleklerde gençleri eğitmeye ihtiyaç olduğu sonucuna varıldı: Erkekler için ziraatçı, makinist, radyocu, elektrikçi, demirci, dökmeci, tesviyeci (tornacı), kimyager, mimar, mühendis, inşaat ustası, öğretmen, bankacı, muhasip, maliyeci, doktor, veteriner, ormancı; kızlar içinse öğretmen ve ebe. ${ }^{82}$ Bir yandan da Söz ve Yankı gazetelerine mesleklerle ilgili ilânlar verildi. Türkiye'de okumak isteyen öğrenci adayları, bu ilânlara bakarak KATAK'a başvurmaya başladı. Belirlenen mesleklerin yanı sıra adayların okumak talebiyle başvurduğu diğer meslekler şunlardı: hukuk, güzel sanatlar, eczacılık, edebiyat, el sanatları, terzilik, hastabakıcılık, kozmetik sanayi ve dülgerlik. ${ }^{83}$

Adanın değişik bölgelerinden Türkler, yüksek öğrenim için Kurum'a müracaatta bulunmaktaydı. Baflı Cavit Ramadan, önce diş doktorluğunu seçmiş, daha sonra fikir değiştirerek yüksek ziraat okuluna gitmek istediğini belirtmişti. ${ }^{84}$ Mağusa'dan Konedralı (Gönendere) Aydoğdu Hasan Oktay da dilekçesinde eczacilık okuma talebini dile getirmişti. ${ }^{85}$ Dilekçe sahipleri içinde her iki mesleği tercih edenler de olmuştu. Salih

\footnotetext{
${ }^{80}$ K.T.Y.04.1946.74.03; K.T.Y.04.1946.75.01;K.T.Y.04.1946.106.01.

81 Denktaş, a.g.e., s.87, 131; K.T.Y.04.1945.195.04; K.T.Y.04.1944.132.01;K.T.Y.04. 1947.

07.01;K.T.Y.04. 1947. 08.01;K.T.Y.04. 1947. 30.02.

${ }^{82}$ K.T.Y.04.1945.12.01; K.T.Y.04.1945.12.02; K.T.Y.04.1945.12.05; K.T.Y.04.1945.13.02.

${ }^{83}$ K.T.Y.04.1944.254.01;K.T.Y.04.1945.56.01;K.T.Y.04.1945.27.01;K.T.Y.04.1945.55.01;K.T.

Y.04.1944.301.01;K.T.Y.04.1944.304.04; K.T.Y.04.1944.305.01; K.T.Y.04.1944.307.02.

${ }^{84}$ K.T.Y.04.1945.161.01;K.T.Y.04.1945.148.01.

${ }^{85}$ K.T.Y.04.1945.101.01.
}

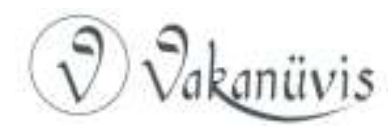


Şükrü isimli bir aday; muhasiplik ve bankacılık için müracaat etmişti. ${ }^{86}$ Lefkoşa'dan öğrenci adayı Hasan Adnan; kimyagerlik veya kimya öğretmenliği için başvururken ${ }^{87}$; Kaya Arif Hikmet de mimarlık ve kimyagerliği tercih ettiğini bildirmişti. ${ }^{88} \mathrm{~K} ı$ öğrencilerden Pervin Salih Mecit ise diş doktorluğu öğrenimi görme isteğinde bulunmuştu. ${ }^{89}$ Bunun üzerine KATAK, dilekçeleri ele alarak muhasiplik ve bankacilığa Salih Şükrü'nün, mimarlığa Kaya Arif Hikmet'in, kimyagerliğe Hasan Adnan'ın, diş doktorluğuna ise Pervin Salih Mecit'in tercih edilmesine ilişkin önerilerini azalarının değerlendirmesine sundu. ${ }^{90}$ Konuyla alakalı arşiv belgelerinde Kurum'un Lârnaka ${ }^{91}$ ve Limaso| ${ }^{92}$ 'daki azalarının bu teklife olumlu cevap verdikleri görülmektedir. Belgelerin sınırlılığından ötürü Mağusa ve Baf'taki azaların genel merkeze hangi görüşü ilettiği bilinmemektedir. Ancak KATAK'ın Türkiye'ye öğrenci göndermeyi bir görev hâline getirdiği göz önünde bulundurulduğunda, söz konusu kasabalardaki azaların da teklife onay verdikleri düşünülebilir.

Kurum'un Kıbrıslı Türklere meslek kazandırma yönündeki bir diğer faaliyeti de zanaatkâra destek vermesiydi. ${ }^{93}$ Bu alandaki başlıca faaliyet; Türk esnaf ve zanaatkârına borç para temin edilmesiydi. Nitekim Lârnaka'nın Petrofani (Esendağ) köyünden İbrahim Ahmet'e Lefkoşa'ya bağlı Lurucina (Akıncılar) köyünde demircilik sanatını öğretmek, yine başkentin Amadyez (Günebakan) köyünden Hüsnü Osman'a Dillirga'da demircilik yapmak, Mağusalı demircilerden Hasan Salih'e ise sermayesini genişletmesi için KATAK tarafından borç verildi. ${ }^{94}$

Esnaf ve zanaatkâra yapılan maddi yardımın, aynı zamanda Kıbrıs Türk toplumunun başta Rumlar olmak üzere başka milliyetlere mensup toplumlara olan ekonomik bağımlılı̆ını azaltmaya yönelik olduğu anlaşılmaktaydı. Nitekim Lârnakalı Aliye Hasan'ın 13 Temmuz 1944 tarihli dilekçesinde, açacağı kuaförlük dükkânına alacağı alet ve ilaçlar
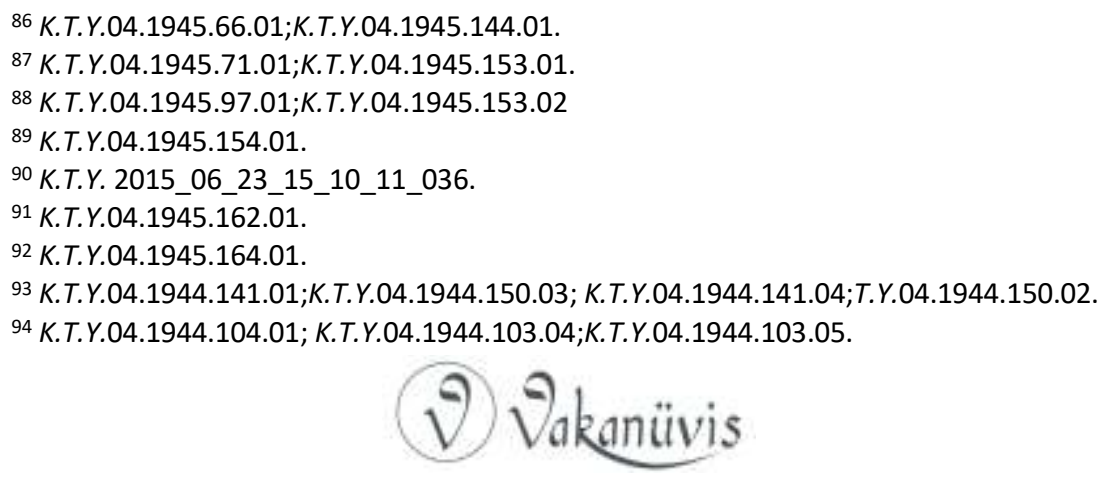
için istediği borç para ${ }^{95}$, birkaç ay sonra KATAK tarafından sağlandı. ${ }^{96}$ Burada dikkat çekici olan nokta, Kurum'un Lârnaka Şubesi Sekreteri'nin 20 Ağustos'ta Genel Sekreter Korkut'a yazdığı yazıda, Türk kadınlarının parasının Rum kuaföre gitmesini önlemek için Aliye Hasan'ın taleplerinin karşılanmasını tavsiye etmesiydi. ${ }^{97}$ Aynı şekilde 1945 yılında KATAK, Lârnaka'da Türk demirci, makinist veya tenekeci bulunmadığından hareketle bölgeye bir dükkân açmaya karar veren Mustafa Yeşim'e gerekli aletleri alabilmesi için borç para verilmesi kararını aldı. ${ }^{98}$

Kıbrıslı Türklerin meslekî ve ekonomik gelişimiyle ilgilenen KATAK, Türklük bilincini yeni nesillere aktarmak için de çaba harcadı. Bunun altında yatan sebep; kuvvetli ve köklü Türk aleyhtarlığı barındıran Kıbrıs Rum milliyetçiliğini dengeleme düşüncesi olmalıydı. Kurum'un bu çabasını başarıya ulaştıracak tarihsel koşullar da oluşmuş vaziyetteydi. Nitekim İstiklâl Harbi günlerinde Kıbrıs Türk toplumu, savaşın başarısı için Anadolu halkına maddi destek sağlayan çeşitli bağış kampanyaları tertiplemişti. ${ }^{99}$ Türkiye Cumhuriyeti'nin ilk yıllarında ise Kıbrıslı Türkler, Cumhurbaşkanı Atatürk'ün liderliğinde yapılan inkılâpları çok yakından takip edip kendi toplumsal yaşantılarına birebir uygulamaya gayret etmişlerdi. ${ }^{100}$ Böylece Kıbrıs Türk toplumu içinde Türk milletine aidiyet duygusu gelişip güçlenmişti. Söz konusu bayramlar, Kıbrıslı Türklerin hem adanın Yunanistan tarafından ilhak edilmesi tehlikesine karşı toplumsal birliklerini güçlendirmeleri, hem de millî kimliklerini kazanıp korumalarında önemli bir rol oynamaktaydı. Diğer bir deyişle bu millî günler, Türk toplumuna enosis fikriyle mücadele edebilmek için ihtiyaç duyduğu ideolojik temeli sağııyordu. Kıbrıs Türk gençliğine millî bilinç kazandırmak amacında olan KATAK'ın Türk millî bayramlarının kutlanmasına öncülük etmesi, bu sürecin doğal bir sonucu olarak görülebilirdi.

Kurum'un 1944'te 19 Mayıs Atatürk'ü Anma, Gençlik ve Spor Bayramı'nın Kıbrıs'ta kutlanmasına öncülük etme kararı alması, bunun

\footnotetext{
${ }^{95}$ K.T.Y.04.1944.142.01; K.T.Y.04.1944.174.05.

${ }^{96}$ K.T.Y.04.1944.232.07.

${ }^{97}$ K.T.Y.04.1944.174.01; K.T.Y.04.1944.174.02.

${ }^{98}$ K.T.Y.04.1945.215.02; K.T.Y.04.1945.215.01; K.T.Y.04.1945.231.03.

99 İsmail ve Birinci, iki Ulusal Kongre, s. 38-44.

100 İsmail ve Birinci, Atatürk Döneminde Türkiye-Kıbrıs ilişskileri (1919-1938), s. 218-274.
}

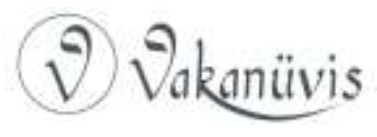


en çarpıcı örneklerinden biriydi. Nitekim karar, KATAK'ın ileri gelenleri arasında memnuniyet yarattı. Bunu Kıbrıslı Türklerin varlıklarını dünyaya duyurmalarını sağlayacak bir fırsat olarak gördüler. Hatta içlerinde toplumsal birlik hâlinde kutlama olması için bütün kaza ve köylerde bulunan Türk spor kuruluşları ve kulüpleri ile görüşülmesini önerenler oldu. ${ }^{101}$ Bu görüşleri göz önünde bulunduran KATAK, hemen çalışmaya geçerek kutlamaları tertip edecek bir "Müfrez Komisyon" kurdu. Komisyon aldığı karar doğrultusunda ${ }^{102}$, başta İslam Lisesi ile Viktorya Kız Okulu olmak üzere Lefkoşa okullarındaki bütün Türk öğrencilerin 19 Mayıs kutlamalarına katılabilmesi için ilgili makamlardan gereken izinleri aldı. ${ }^{103}$ Böylece Halk Kulübü gibi Türkleri temsil eden diğer kuruluşların ${ }^{104}$ ve Kıbrıs Türk gençliğinin katılımıyla başkentin Hisaraltı bölgesinde atletizm yarışmalarının da düzenlendiği bir kutlama etkinliği gerçekleştirildi. ${ }^{105}$

Aynı yıl benzer bir kutlama, 29 Ekim Cumhuriyet Bayramı için de yapıldı. Bu amaç için 11 Ekim'de Kıbrıs Türk toplumunu temsil eden çeşitli kurumlarla bir araya gelen KATAK, tören hazırlıklarını yapacak bir müfrez komisyon oluşturdu. ${ }^{106}$ Komisyon, 18 Ekim'de toplantı yaparak bir tören programı hazırladı. ${ }^{107} \mathrm{Bu}$ arada gerek kutlama için İslam Lisesi'ne ait avlunun kullanılması, gerekse ilkokul ve ortaokullardaki Türk öğrenci ile öğretmenlerinin törende yer alabilmesi için de resmi makamlardan izin alındı. ${ }^{108}$ Böylece 29 Ekim günü Cumhuriyet Bayramı, önde gelen liselerin Türk öğretmen ve öğrencilerinin de hazır

\footnotetext{
${ }^{101}$ K.T.Y.04.1944.96.01.

102 K.T.Y.04.1944.106.07.

${ }^{103}$ K.T.Y.04.1944.106.03; K.T.Y.04.1944.106.05.

104 K.T.Y.04.1944.106.04.

105 K.T.Y.04.1944.119.01.

${ }^{106}$ K.T.Y.04.1944.198.03; K.T.Y.04.1944.210.01; K.T.Y.04.1944.211.01; K.T.Y.04.1944.212. 01.

${ }^{107}$ K.T.Y.04.1944.216.01; K.T.Y.04.1944.218.01; K.T.Y.04.1944.218.04: K.T.Y.04.1944.220.

01; K.T.Y.04.1944.226.03; K.T.Y.04.1944.226.04; K.T.Y.04.1944.223.01.

${ }^{108}$ K.T.Y.04.1944.197.01; K.T.Y.04.1944.228.02; K.T.Y.04.1944.229.01; K.T.Y.04.1944.230.

04; K.T.Y.04.1944.231.02; K.T.Y.04.1944.11.01;K.T.Y.04.1944.11.02; K.T.Y.04.1944.13.01.
}

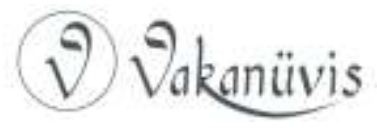


bulunmasıyla ${ }^{109}$ kutlandı. ${ }^{110}$ Bu etkinlikler, 1944 yılıyla sınırlı kalmadı. Özellikle Cumhuriyet Bayramı kutlamaları, sonraki yıllarda da KATAK'ın öncülüğünde sürdürüldü. ${ }^{111}$

\section{Sonuç}

KATAK, Kıbrıs Türk toplumunun örgütsüz olduğu veya neredeyse hiç örgüt tecrübesinin bulunmadığı koşullarda, adadaki Türkleri birleştirmeyi başarmış; sonraki yıllarda ortaya çıkan Kıbrıs Türk örgütlerinin de zeminini hazırlamıştır. Nitekim gerek Dr. Küçük'ün önderliğindeki siyasi partiler, gerekse Kıbrıs Türk Kurumları Federasyonu (KTKF) gibi kurumlar; KATAK deneyiminden öğrenerek veya ders çıkararak siyasetlerini belirleyip uygulamışlardır. Bunun yanı sıra KATAK, çeşitli alanlarda yaptığı girişim ve çalışmalarla hem Kıbrıslı Türklerin toplumsal ilerlemelerine önemli katkılarda bulunmuş; hem de gelecekteki benzer faaliyetlerin altyapısını oluşturmuştur. Kurum'un eğitim, ekonomi ve kültür alanlarında başlattığı çalışmalar; Türk toplumu üzerindeki etkisinin azaldığı 1949 yılından sonra da devam ettirilmiştir. Bu çalışmalar, 1950'li yıllarda KTKF tarafından yürütülen "Vatandaş Türkçe Konuş", "Türk'ten Türk'e Kampanyası" gibi değişik kampanyalarla pekiştirilip kurumsallaştırılmıştır. Dahası Kıbrıs Türk toplumu, bu faaliyetler neticesinde kazandığı birikim ve donanımla kendi kendini yönetebilecek olgunluğa erişmiştir. Bu açıdan bakıldığında KATAK'ın burada özetlenen bütün bu süreçlerin başlatıcısı veya öncüsü olduğu söylenebilir.

\section{Kaynakça}

\section{Arşiv Belgeleri}

\footnotetext{
109 KATAK yönetiminin isteği üzerine etkinliğe katılacağını bildiren okullar ile öğretmen ve öğrenci sayıları şöyleydi: Ayasofya Kız Okulu 350 öğrenci, 25 öğretmen; Haydarpaşa Okulu 188 öğrenci, 11 öğretmen; Viktorya Kız Okulu 149 öğrenci, 10 öğretmen; bkz. K.T.Y.04.1944.236.02; K.T.Y.04.1944.236.05; K.T.Y.04.1944.238.01; K.T.Y.04.1944.236.11; K.T.Y.04.1944.240.02; K.T.Y.04.1944.245(a).03; K.T.Y.04.1944.248.01; K.T.Y.04.1944. 249.01.

${ }^{110}$ K.T.Y.04.1944.293.02.

${ }^{111}$ K.T.Y.04.1945.214.01;

K.T.Y.04.1945.214.02;K.T.Y.04.1945.214.03;K.T.Y.04.1945.216.03;K.T.Y.04.1946.84.01; K.T.Y.04.1946.84.02; K.T.Y.04.1946.86.01; K.T.Y.04.1946.86.02.
}

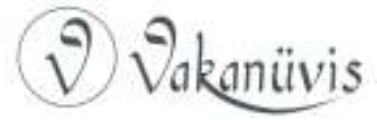


"Atlantic Charter", https://www.unmultimedia.org/searchers/yearbook/ page.jsp?volume $=1946-47 \&$ page $=37 \&$ srq $=$ atlantic $\&$ srstart $=0 \&$ srvolumeFacet =1946-47\&sroutline=false\&searchType=advanced, (24.11.2018).

KKTC Millî Arşiv Belgeleri (K.T.Y.)

HL Deb, 31 March 1943, vol 126, c1036, https://api.parliament.uk/historichansard/lords/1943/mar/31/cyprus, 29.11.2018.

\section{Kitaplar}

Alasya, Halil Fikret, Kıbrıs Tarihi ve Kıbrıs'da Türk Eserleri, Ankara 1977.

An, Ahmet, Dinsel Toplumdan Ulusal Topluma Geçiş Süreci ve Kıbrıs Türk Liderliğinin Oluşması (1900-1942), Lefkoşa 1997.

Beratlı, Nazım, Kıbrıslı Türklerin Tarihi, Ingiliz Dönemi, Lefkoşa 1999.

Crawshaw, Nancy, The Cyprus Revolt, An account of the struggle for union with Greece, London 1978.

Denktaş, Rauf Raif, Elli Yılın Hikâyesi, İstanbul 2008.

Gazioğlu, Ahmet C., Ingiliz Yönetiminde Kıbrıs II (1878-1952), Enosis Çemberinde Türkler, Bugünlere Gelmek Kolay Olmadı (1), Lefkoşa 2000.

Gürkan, Haşmet M., Bir Zamanlar Kıbrıs'ta (Tarih yazıları) (1860-1945), Lefkoşa 1986.

Hill, George, A History of Cyprus, The Ottoman Province. The British Colony, 1571-1948, Cambridge 2010.

İsmail, Sabahattin ve Ergin Birinci, Kıbrıs Türkünün Varoluş Savaşımında iki Ulusal Kongre, Meclis-i Milli (1918), Milli Kongre (1931), Lefkoşa 1987.

İsmail, Sabahattin ve Ergin Birinci, Atatürk Döneminde Türkiye-Kıbrıs iliş̧kileri (1919-1938), Lefkoşa 2000.

Keser, Ulvi, Çanakkale Esirleri, Ermeni Doğu Lejyonu, Milli Mücadele, Dr. Behiç Bey, EOKA, Türk Mukavemet Teşkilatı, KTKF, Megali idea, Ermeniler, 20 Temmuz 1974 ve Annan Planında, Dünden Bugüne Kıbrıs (1913-2013), Ankara 2013.

Kızılyürek, Niyazi, Milliyetçilik Kıskacında Kıbrıs, İstanbul 2002.

Kürşad, Fikret, Mustafa Haşim Altan, Sabahattin Egeli, Belgelerle Kıbrıs'ta Yunan Emperyalizmi, İstanbul 1978.

Manizade, Derviş, Kıbrıs, Dün, Bugün, Yarın, İstanbul 1975.

Uçarol, Rifat, 1878 Cyprus Dispute\&The Ottoman-British Agreement, Lefkoşa 2000.

Ünlü, Cemalettin, Kıbrıs'ta Basın Olayı, Ankara 1981.

\section{Makaleler}

Akgün, Sibel, "1942-1943 Arası Dönemde Kıbrıs Türk Kimliğinin illk Kurumsallaşma Hareketleri”, Turkish Studies, 7/3, (2012), s.127-143. 
Öztoprak, İzzet, "Kıbrıs'ta 1931 İsyanı ve Yankıları (3 sayfa belge ile birlikte)”, Belleten, LXII/233, (1998), s.207-236.

Sonyel, Salâhi R., "Ingiliz Yönetiminde Kıbrıs Türklerinin Varlık Savaşımı", Belleten, LIX/224 (1995), s.133-188. 


\section{EKLER}

Kıbrıslı Türklerin KATAK'a Gönderdiği Dilekçelerden Örnekler

\section{EK-1}

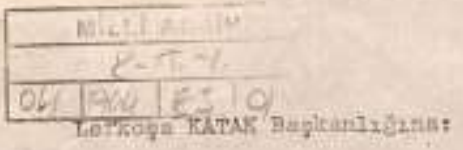

Latticet 15.9 .64

Beratiut

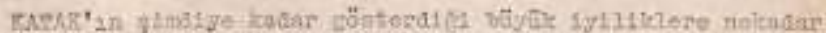

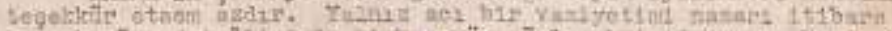

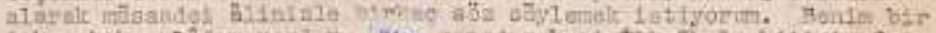

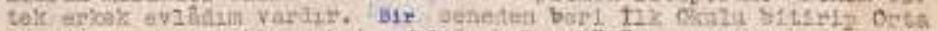

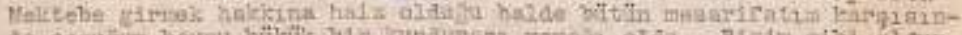
ca cost

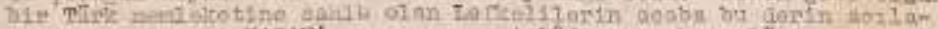

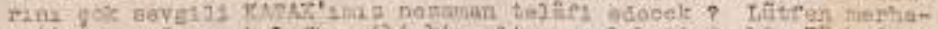

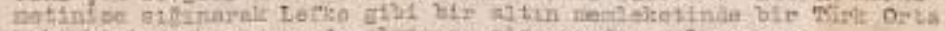

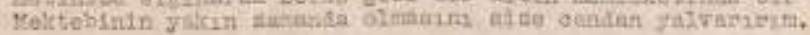




\section{EK-2}

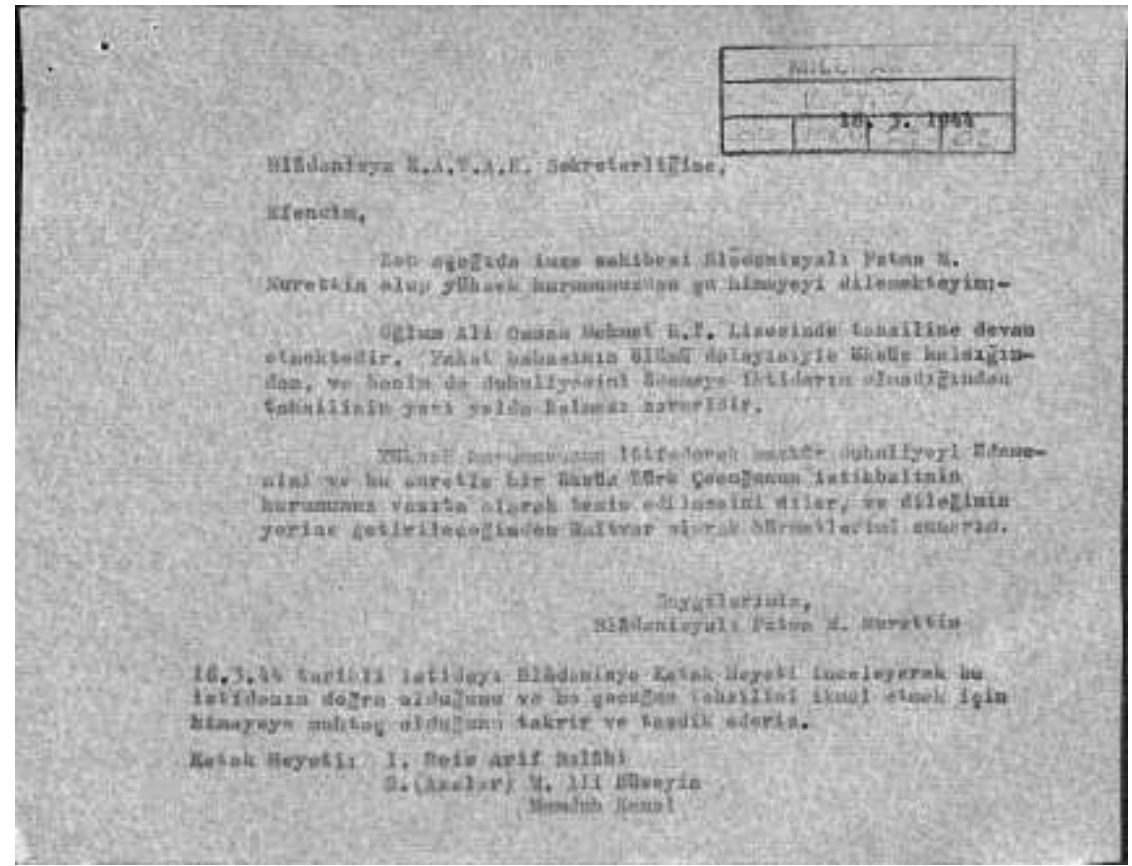

( V) Vakaniivis 


\section{EK-3}

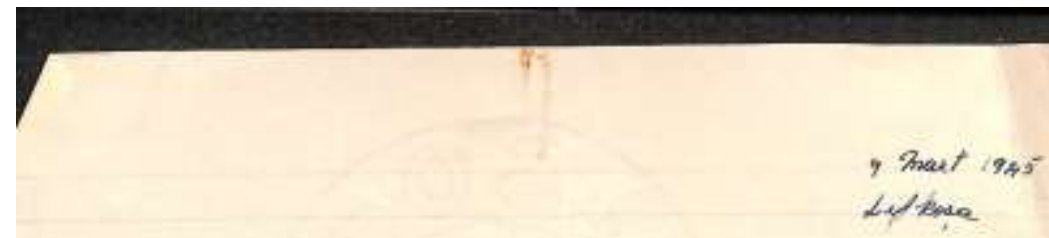

Sayzen K.A.T:A.K Baskanuna

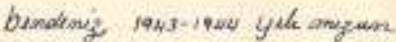

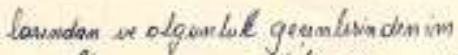

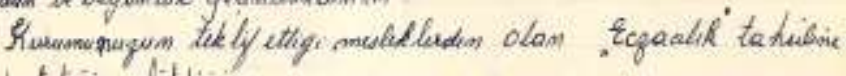
gitone untidi gion bidaisiom.

$$
\text { sayp, ite }
$$

Aydog due Hasers oktay

Bdres Agdogider Hawan Oblay

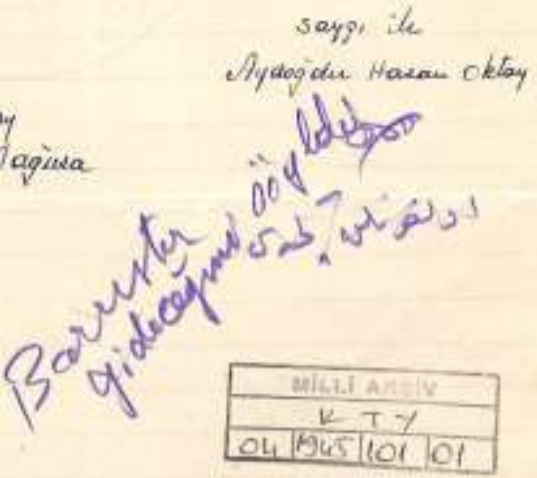

Korrde _ Maginta

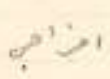

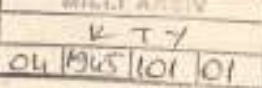




\section{EK-4}

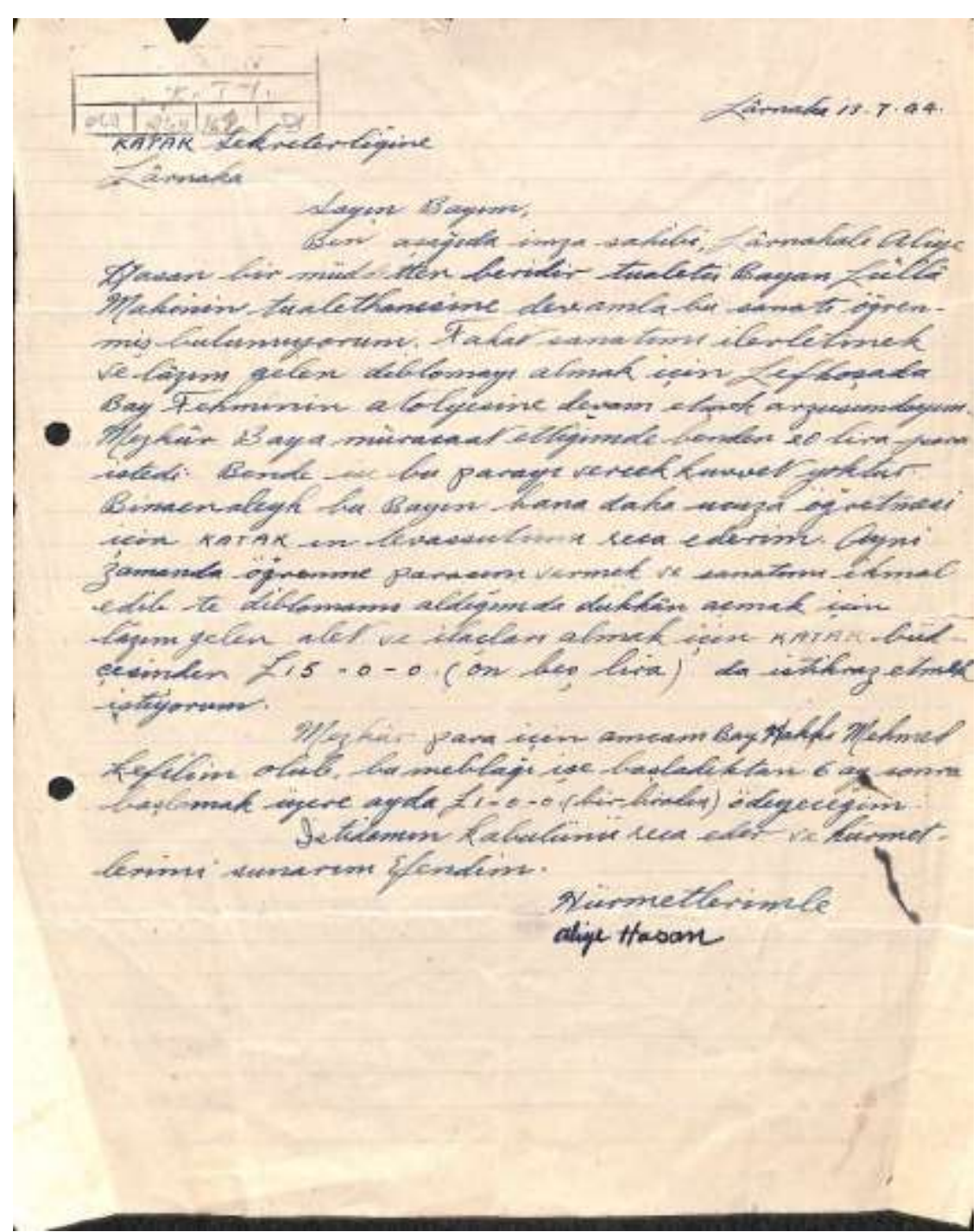




\section{EK-5}

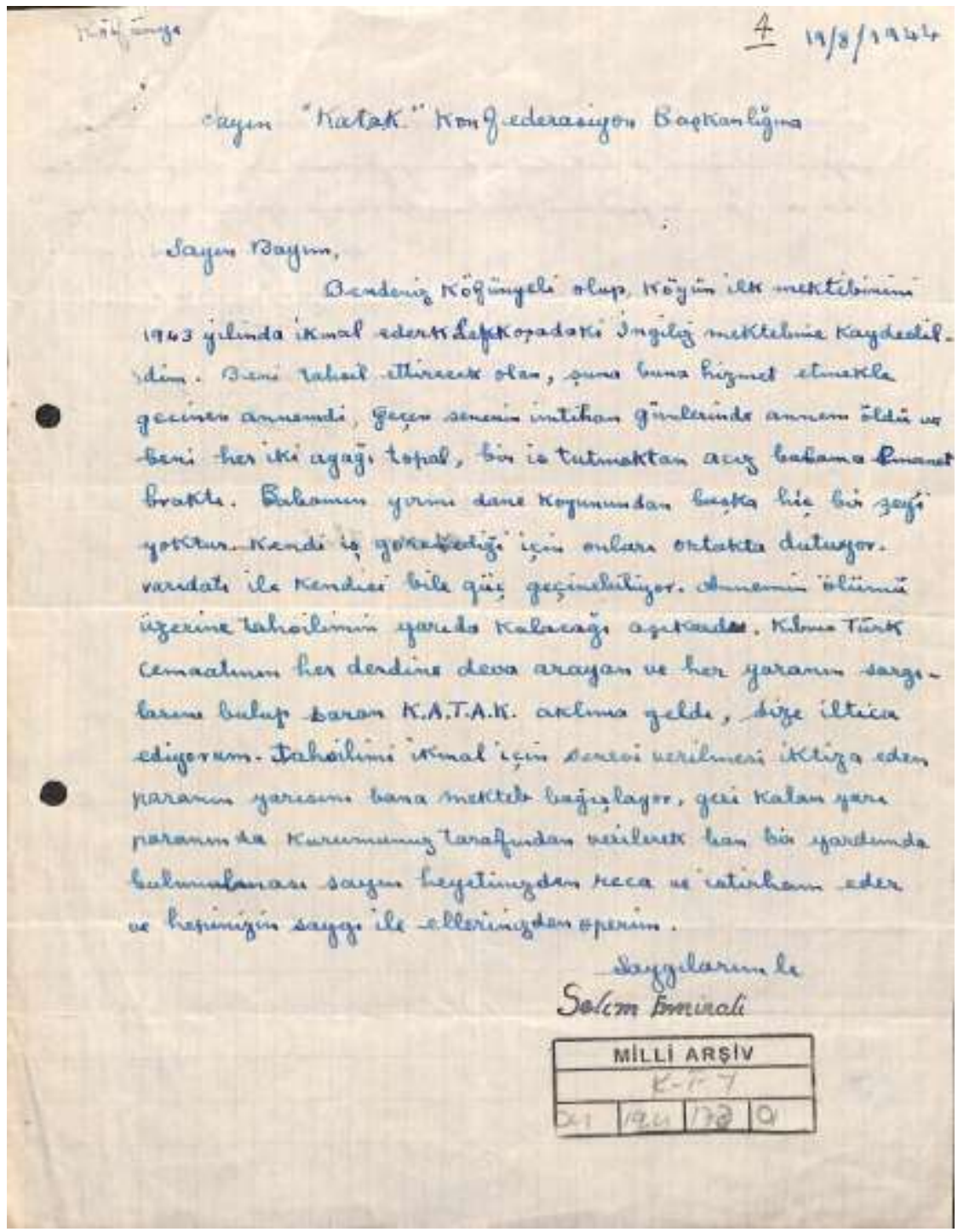

